\title{
PROSPECÇÃO DE MICROEMPRESA NO COMÉRCIO EXTERIOR ATRAVÉS DA ADOÇÃ̃O DAS LOGÍSTICAS DO COMÉRCIO ELETRÔNICO E EXPORTA FÁCIL
}

\author{
Sidney Saraiva Maia Júnior \\ Graduado em Tecnologia em Comércio Exterior pelo Instituto Federal de Educação, \\ Ciência e Tecnologia do Rio Grande do Norte - IFRN \\ Raimundo Nonato Camelo Parente \\ Graduado em Administração de Empresas pela Universidade Estadual do Ceará (1987), \\ especialização em Comércio Exterior pela Universidade Católica de Brasília (2004), \\ mestre em Sistemas e Computação pela UFRN (2002). Atualmente é professor do IFRN. \\ Tem experiência na área de Ciência da Computação. E-mail: rnonato@cefetrn.br
}

\section{RESUMO}

Este estudo tem como objetivo avaliar a viabilidade de inserção de microempresa brasileira no comércio internacional adotando um modelo que prega o e-commerce como meio de divulgação e redução de despesas administrativas, bem como o "exporta-fácil" como ferramenta logística. A análise se dá em duas etapas: primeiro considerando as vantagens competitivas constatadas na literatura para, em seguida, efetuar análise de viabilidade financeira através de comparativo loja versus loja virtual a partir dos cálculos de margem de contribuição e ponto de equilíbrio. A metodologia utilizada neste estudo se consistiu numa pesquisa exploratória descritiva feita através de livros, artigos científicos, monografias e sítios da Internet. Foram colhidos também dados quantitativos através do uso de questionário, bem como foram realizadas entrevistas com empreendedores. Constatou-se que o modelo em questão é financeiramente viável e ainda apresenta diversas vantagens, tanto ao empresário quanto ao consumidor geradas, principalmente, pelo seu baixo custo operacional.

PALAVRAS-CHAVE: Microempresa; Comércio Eletrônico; Exporta-fácil; Comércio Exterior; Análise de viabilidade; Margem de Contribuição; Ponto de Equilíbrio.

\begin{abstract}
This work seeks to evaluate whether it is viable or not to launch Brazilian microbussiness into international commerce using a model that suggests e-commerce as a way to gain publicity and lower management costs, as well as the "exporta-fácil" as a logistic tool. The analysis occurs in two stages: competitive advantages seen in bibliography are considered proceeding to a study on financial viability comparing a traditional store to a virtual version of itself done by calculating their contribution margin and also their point of balance. The methodology utilized in this study was descriptive-exploratory, done through books, scientific articles, monographies and internet sites. Quantitative data has also been collected through the use of questionnaires and interviews. It has been concluded that the model is financially efficient and also presents many benefits both to the businessman as well as to the consumer, generated by its low costs.
\end{abstract}


KEY-WORDS: Microbusiness; e-commerce; Exporta-fácil; Internacional Commerce; Viability analysis; Point of balan 


\section{PROSPECÇÃO DE MICROEMPRESA NO COMÉRCIO EXTERIOR ATRAVÉS DA ADOÇÃ̃O DAS LOGÍSTICAS DO COMÉRCIO ELETRÔNICO E EXPORTA FÁCIL}

\section{INTRODUÇÃO}

É notória a importância das microempresas na economia brasileira. Nestes termos, toda e qualquer contribuição no intuito de viabilizar maiores condições de competição para este tipo de negócio no mercado é extremamente válida.

Embora já se observe a aliança entre o comércio eletrônico ou o exporta fácil aos pequenos negócios no meio acadêmico, é escassa, até o momento, bibliografia que explore simultaneamente essas duas ferramentas em prol do empreendedor. Neste sentido, torna-se notória a relevância do trabalho neste meio.

No tocante à comunidade, a contribuição do estudo é explícita quando consideramos o número de indivíduos relacionados direta ou indiretamente com as microempresas. Um estudo que beneficia este tipo de empreendimento acarreta, consequientemente, benefícios para a população.

Para o pesquisador integrante, o tema "comércio eletrônico" sempre se mostrou interessante, dada sua afinidade com este campo de estudos. Neste sentido, a necessidade de formulação e pesquisa de estratégias para o uso de tal ferramenta aliada ao tema central do curso de Tecnologia em Comércio Exterior - os processos de importação e exportação e aspectos intervenientes no Brasil - surgiu naturalmente e culminou na confecção deste estudo.

Com o objetivo de classificar esta pesquisa, foram utilizadas as tipologias de Gil (2002) e Vergara (2000). Baseado em Vergara, podemos considerar o tipo de pesquisa empregada, no que tange seu fim (Gil denomina objetivo da pesquisa), como exploratório. Exploratório, no sentido lato do termo, dado que foram apresentados também aspectos descritivos e explicativos, visando localizar e fundamentar a exploração do caso.

Para tanto, se fez necessária uma análise descritiva dos fenômenos envolvidos neste processo e como os diversos fatores envolvidos nestes fenômenos contribuíram para a ocorrência dos mesmos.

O estudo pode ser classificado como exploratório, dado que busca "proporcionar maior familiaridade com o problema, com vistas a torná-lo mais explícito" (GIL, 2002). O trabalho se caracteriza, então, como uma pesquisa exploratório-descritiva, uma vez que busca estudar e descrever o uso da tríade microempresa, comércio eletrônico e exporta fácil.

Assim, por meio de um levantamento doutrinário e bibliográfico, houve a coleta das informações referentes ao assunto em questão, auxiliando a realização de um embasamento teórico e balizando a linha de pensamento seguida. Esse levantamento foi composto por vários documentos dos assuntos afins ao trabalho, analisando sempre as autoridades no assunto. São documentos como: artigos de revista especializados, artigos da internet, 
websites, artigos de jornais locais e regionais, artigos científicos, monografias e livros, que sustentaram a base da pesquisa.

Além dos dados qualitativos, que buscam a estruturação teórica do trabalho, utilizou-se dados quantitativos, auxiliados pela estatística descritiva e seus instrumentos, para a melhor apreensão do contexto e do conteúdo trabalhado.

O universo de pesquisa é definido por micro e pequenas empresas em funcionamento as quais almejam ingressar no mercado internacional sem necessidade de investimentos demasiadamente onerosos. Já a amostragem de pesquisa é definida por microempresa atuante no comércio varejista local no segmento de calçados, bolsas e acessórios.

Este trabalho tem como objetivo geral analisar o funcionamento da tríade MicroempresaComércio Eletrônico-"Exporta Fácil" no sentido de minimizar custos e potencializar maior retorno financeiro no comércio exterior.

Especificamente, o estudo busca compreender o funcionamento do comércio eletrônico na divulgação e venda dos produtos/serviços das empresas; compreender o funcionamento do Exporta Fácil alavancando vendas nas microempresas; e estabelecer estratégia competitiva exportando via Internet/Exporta Fácil.

Tendo em vista essa discussão, surge espaço para a seguinte problemática de pesquisa:

Existem vantagens competitivas para uma microempresa que se lança no comércio exterior através do comércio eletrônico fazendo uso do "Exporta Fácil" como ferramenta logística?

\section{VANTAGENS DO USO DA TRÍADE MICROEMPRESA, COMÉRCIO ELETRÔNICO E EXPORTA FÁCIL COMO GERADORA DE COMPETITIVIDADE NO COMÉRCIO EXTERIOR}

Através de consulta ao ALICE-Web ${ }^{1}$ do MDIC, é possível constatar o enorme potencial agroexportador brasileiro, o qual remete aos tempos do período colonial. Infelizmente, a exploração desse potencial exportador se dá, em sua maior parte, por empresas de grande porte na Tabela 1.

Considerando a situação peculiar em relação aos modelos de negócios envolvidos nas transações e sua participação nas exportações nacionais, comprovada através de informações do Ministério do Desenvolvimento, Indústria e Comércio Exterior, demonstradas na Tabela 1 abaixo, nota-se que em 2008, em quantidade, as micro e pequenas empresas responderam por aproximadamente $50 \%$ das exportações brasileiras contra $24 \%$ das grandes empresas. No entanto, Em valor, as micro e pequenas empresas

\footnotetext{
${ }^{1}$ O Sistema de Análise das Informações de Comércio Exterior via Internet, denominado ALICE-Web, da Secretaria de Comércio Exterior (SECEX), do Ministério do Desenvolvimento, Indústria e Comércio Exterior (MDIC), foi desenvolvido com vistas a modernizar as formas de acesso e a sistemática de disseminação dos dados estatísticos das exportações e importações brasileiras. O ALICE-Web é atualizado mensalmente, quando da divulgação da balança comercial, e tem por base os dados obtidos a partir do SISCOMEX (Sistema Integrado de Comércio Exterior), sistema que administra o comércio exterior brasileiro. Fonte: Alice Web (2010).
} 
responderam apenas por $1,16 \%$ enquanto as grandes empresas foram responsáveis por $95 \%$ em US\$ FOB.

Tabela 1 - Exportação brasileira por porte de empresa (2008)

\begin{tabular}{|c|c|c|}
\cline { 2 - 3 } \multicolumn{1}{c|}{} & Quantidade & Valor US\$ FOB \\
\hline Total Geral & 23.032 & 197.942 .442 .909 \\
\hline Micro Empresa & 5.054 & 267.259 .637 \\
\hline Pequena Empresa & 6.066 & 2.042 .103 .284 \\
\hline Média Empresa & 5.793 & 8.899 .874 .080 \\
\hline Grande Empresa & 5.508 & 186.388 .505 .084 \\
\hline Pessoa Física & 611 & 344.700 .824 \\
\hline
\end{tabular}

Fonte: MDIC, 2009.

Tais dados levam a refletir sobre a participação das micro e pequenas empresas uma vez que, em 2001, esses modelos de negócio empregavam 7,3 milhões de pessoas: 60,8\% do pessoal ocupado nos setores de comércio e serviços, segundo pesquisa do IBGE (2003). Fica clara, assim, a importância das micro e pequenas empresas, não só para o mercado de trabalho nacional, como também para o desenvolvimento da economia nacional.

Surgem, então, questionamentos acerca de como proceder no sentido de facilitar a concorrência de pequenas e, mais especificamente, microempresas no comércio exterior frente à supremacia das grandes empresas com maior disponibilidade de capital para investimentos e divulgação dos produtos no exterior.

Como ferramenta para tal situação, este trabalho considera o comércio eletrônico como alternativa, seguindo as idéias de Elsenpete e Velte (2002), defensores da tese de que a Internet é um instrumento de equanimidade considerando que tudo é disponibilizado aos clientes da mesma maneira, ou seja, por meio do computador, à revelia da forma pela qual os produtos são apresentados. Não importando se o negócio seja uma pequena butique de bairro, enquanto o concorrente tenha uma loja no shopping mais sofisticado da cidade.

Contudo, quando elevamos estas relações ao âmbito do comércio internacional, surgem novos desafios nos níveis estratégicos, operacionais e logístico gerando a necessidade do uso de novos processos de negócios e novas ferramentas na tentativa de sua transposição.

Neste sentido, o micro empresário conta com uma série de políticas governamentais no intuito de incentivar as exportações, tendo em vista a importância destas para que se atinja o sempre almejado superávit na balança comercial, sejam estas no âmbito dos incentivos fiscais ou até a criação de meios físicos - o que nos direciona a uma ferramenta específica a ser tratada neste trabalho: o "Exporta Fácil", criado tendo como uma de suas metas diminuírem as barreiras logísticas à exportação para micro e pequenas empresas.

O serviço Exporta Fácil dos Correios foi desenvolvido com a parceria da Receita Federal, BACEN, SECEX, CAMEX e de outros órgãos relacionados às exportações, tendo como objetivo simplificar os processos postais e alfandegários. 
O Exporta Fácil está disponível nas 12 mil agências da ECT dispostas por todo o Território Nacional, permitindo que exportadores de cidades menores, onde não há alfândega, façam suas exportações sem a necessidade de se deslocar para outras cidades maiores.

De acordo com o exposto, serão caracterizados estes três agentes (microempresa/comércio eletrônico/Exporta Fácil) a fim de correlacioná-los na pesquisa a ser realizada, no intuito de se demonstrar sua viabilidade no comércio internacional.

Para que a implementação de uma ferramenta seja viável a uma empresa ou organização, essa terá de agregar vantagens competitivas levando em conta que a mesma surge fundamentalmente do valor que uma determinada empresa consegue criar para os seus clientes e que ultrapassa os custos de produção, conforme sugerido por Porter (1989).

É interessante, também, que estas vantagens competitivas sejam alcançadas com baixo custo de implementação possível a fim de maximizar a possibilidade de lucro. A análise da tríade em questão se dará com esta perspectiva como referencial.

\section{CARACTERÍSTICAS GERAIS DAS MICROEMPRESAS}

Inicialmente, surgiu a necessidade de adotar uma definição para o termo microempresas uma vez que não há unanimidade na segmentação destas. Constata-se divergência nos critérios de definição, seja por parte da legislação vigente ou no tangente às instituições financeiras oficiais ou órgãos representativos do setor, conforme podemos observar no Quadro 1 a seguir:

Quadro 1 - Definição de Microempresas

\begin{tabular}{|l|c|c|}
\hline Critérios de Enquadramento & Valor de Receita & $\begin{array}{c}\text { Número de pessoas } \\
\text { ocupadas }\end{array}$ \\
\hline $\begin{array}{l}\text { Lei Complementar } n^{\circ} 123 \text { de } \\
14 / 12 / 2006\end{array}$ & Até 240 mil reais & Até 9 \\
\hline Sebrae & & \\
\hline $\begin{array}{l}\text { BNDES (critério dos países } \\
\text { do Mercosul para fins } \\
\text { creditícios) }\end{array}$ & Até 400 mil dólares (cerca de 940 mil reais) & \\
\hline
\end{tabular}

Fontes: Brasil. Lei Complementar $n^{0}$ 123, de 14 de dezembro de 2006. Institui o estatuto da microempresa e da empresa de pequeno porte; altera dispositivos das Leis nos 8.212 e 8.213, ambas de 24 de julho de 1991, da Consolidação das Leis do Trabalho - CLT, aprovada pelo Decreto-Lei no 5.452, de 10 de maio de 1943, da Lei no 10.189, de 14 de fevereiro de 2001, da Lei Complementar no 63, de 11 de janeiro de 1990; e revoga as Leis nos 9.317, de 5 de dezembro de 1996, e 9.841, de 5 de outubro de 1999. Diário Oficial da União, Poder Executivo, Brasília, DF, 15 dez.2006. p.1. Col. 1; SEBRAE - Serviço Brasileiro de Apoio às Micro e Pequenas Empresas.

Contudo, em estudo analisando dados do ano de 2001, o IBGE (2003) considerou a classificação quanto ao número de pessoas ocupadas ineficiente nos seguintes termos:

“O critério de classificação das MPEs por número de pessoas ocupadas não leva em conta as diferenças entre atividades com processos produtivos distintos, uso intensivo de tecnologia da informação (Internet, e-commerce, etc.) e/ou forte presença de mão-de-obra qualificada, podendo ocorrer em algumas atividades a realização de alto volume de negócios com utilização de mão-de-obra pouco numerosa, como é o caso do comércio atacadista, das atividades de informática e dos serviços técnico-profissionais prestados”. 
Assim, este estudo adotará conceito vigente na Lei Complementar n ${ }^{\circ} 123$ de 14/12/2006, a qual, em seu Capítulo II intitulado "Da Definição de Microempresa e de Empresa de Pequeno Porte", considera microempresas, "o empresário, a pessoa jurídica, ou a ela equiparada, aufira, em cada ano-calendário, receita bruta igual ou inferior a $\mathrm{R} \$ 240.000,00$ (duzentos e quarenta mil reais)".

A fim de buscar mais especificidade e atingir resultados mais expressivos, cabe qualificar as microempresas no intuito de compreender suas maiores dificuldades no tocante a gestão estratégica.

No estudo intitulado “As Micro e Pequenas Empresas Comerciais e de Serviços no Brasil”, tanto as micro quanto as pequenas empresas são caracterizadas pelos seguintes traços conforme demonstrado pelo IBGE (2003):

a) baixa intensidade de capital;

b) altas taxas de natalidade e de mortalidade: demografia elevada;

c) forte presença de proprietários, sócios e membros da família como mão-de-obra ocupada nos negócios;

d) poder decisório centralizado;

e) estreito vínculo entre os proprietários e as empresas, não se distinguindo, principalmente em termos contábeis e financeiros, pessoa física e jurídica;

f) registros contábeis pouco adequados;

g) contratação direta de mão-de-obra;

h) utilização de mão-de-obra não qualificada ou semiqualificada;

i) baixo investimento em inovação tecnológica;

j) maior dificuldade de acesso ao financiamento de capital de giro; e

k) relação de complementaridade e subordinação com as empresas de grande porte.

As características supracitadas culminam para pontos fracos definidos por Porter (1989) como variáveis internas e controláveis que provocam uma situação desfavorável para a organização, em relação ao seu ambiente. É extremamente plausível que registros contábeis pouco adequados venham a causar problemas em possíveis questões tributárias ou até trabalhistas uma vez que é muito pouco provável que um empreendimento com dificuldades de organização conte com uma reserva de numerários para arcar com os direitos de seus funcionários.

Mesmo com a constatação destes pontos fracos na maioria das microempresas, é interessante salientar que sua presença não ocorre na totalidade dos empreendimentos, já que não se tratam, felizmente, de características obrigatórias. A presença dos referidos pontos pode - e deve - ser controlada através do interesse e habilidade do administrador. 
Assim, fica clara a fragilidade deste modelo de empreendimento justificando, juntamente com sua notória importância, a quantidade de políticas públicas com o objetivo de oferecer-lhe maiores condições de competitividade no mercado.

Para tanto, o Governo Brasileiro instituiu a lei ${ }^{\circ}$ 9.841, de 5 de outubro de 1999, que cria o Estatuto da Microempresa e da Empresa de Pequeno Porte, dispondo sobre o tratamento jurídico diferenciado, simplificado e favorecido, previsto nos arts. 170 e 179 da Constituição Federal. Este tratamento jurídico diferenciado diz respeito aos campos trabalhista, administrativo, tributário, previdenciário, creditício e de desenvolvimento empresarial.

No tangente ao tratamento jurídico dado aos campos previdenciário e trabalhista, há a eliminação de exigências burocráticas e de determinadas obrigações acessórias, que podem ser suprimidas para favorecer a empresa em questão. Com relação ao tratamento diferenciado dado ao campo creditício, destaca a lei que caberá ao poder Executivo determinar os mecanismos fiscais e financeiros que incitarão as instituições financeiras privadas a fornecer linhas de crédito específicas para as microempresas e as de pequeno porte.

Já o incentivo no campo de desenvolvimento empresarial dessas instituições se dá com a adoção, pelo Poder Executivo, de mecanismos de incentivos fiscais e financeiros de acordo a capacidade da empresa, visto que estas empresas possuem: incentivos federais na área de pesquisa, desenvolvimento e capacitação tecnológica, em que $20 \%$ dos recursos serão aplicados neste segmento; tratamento diferenciado nos serviços de metrologia e certificação de conformidade prestada por entidades tecnológicas públicas; tratamento diferenciado e favorecido quando atuarem no mercado internacional, em que o Poder Executivo deverá estabelecer medidas de desburocratização e facilitação para a comercialização; dentre outras vantagens previstas na referida lei $\mathrm{n}^{\circ} 9.841$.

Nota-se, também, que o atual cenário globalizado requer das companhias reações ágeis e uma grande capacidade de adaptação. Franco Jr. (2004, p. 81) é defensor da tese de que em condições normais de mercado, independentemente de seu tamanho, os negócios são capazes de gerar lucro. Porém, em condições adversas, as estruturas organizacionais maiores mostram-se burocráticas e, conseqüentemente, lentas. Logo, as empresas menores, dotadas de sistemas de gestão mais simplificados, possuem altíssima capacidade de mudança de posicionamento, o que culmina em maiores chances de aumento na participação de mercado.

\section{COMÉRCIO ELETRÔNICO COMO MEIO DE ACESSO A MERCADOS}

Com o intuito de aumentar o valor agregado aos produtos comercializados internacionalmente pelas microempresas, sem gerar grandes custos financeiros ou investimentos demasiadamente onerosos, urge a necessidade de pesquisar o uso do Comércio Eletrônico como diferencial competitivo.

Com o crescimento das movimentações financeiras por meio da internet, que se deu desde o final dos anos noventa quando empresas passaram a fornecer serviços através da World 
Wide $W e b^{2}$, o Comércio Eletrônico se torna não somente uma ferramenta para a empresa, mas um nicho de mercado a ser explorado.

Segundo O'Brien (2003, p. 191), entende-se por e-commerce ou Comércio Eletrônico a atividade que engloba o processo on-line inteiro de desenvolvimento, marketing, venda, entrega, atendimento e pagamento por produtos e serviços comprados por comunidades mundiais de clientes virtuais, com o apoio de uma rede mundial de parceiros comerciais, onde os sistemas de comércio eletrônico se valem de recursos de internet, intranets, extranets e outras redes de computadores para apoiar cada etapa desse processo.

Neste estágio, torna-se necessário, também, diferenciar os conceitos de e-commerce e ebusiness. Segundo Batista (2004, p.98), o e-business é definido como sendo a estratégia de posicionamento da empresa na internet e o e-commerce como sendo um dos componentes do e-business, que tem o intuito de controlar a atividade de vendas pelo uso de meios eletrônicos.

Cabe, também, assinalar que as transações comercias através de meio eletrônico podem ser classificadas de diversas maneiras. Constatou-se que a classificação mais popular, tanto no meio acadêmico quanto perante a comunidade, leva em conta os participantes da transação. Laudon e Laudon (2004, p. 116), assinalam que os três principais tipos de comércio eletrônico são: empresa-empresa, empresa-consumidor e consumidor-consumidor.

Turban et al. (2004) define estas modalidades da seguinte forma:

- Empresa-para-empresa (B2B): são transações comerciais realizadas em que os vendedores e compradores são empresas;

- Empresa-para-consumidor (B2C): os vendedores são empresas e os compradores são indivíduos;

- Consumidor-para-consumidor (C2C): indivíduos vendem produtos ou serviços a outras pessoas.

Há uma série de outros possíveis participantes em transações comerciais via web, o que torna ainda maior a gama de mercados a se atingir com um negócio virtual. Turban e King (2004, p. 151) apontam, ainda, diversas outras possibilidades,dentre as quais destacamos as seguintes:

- Empresa-para-empresa-para-consumidor (B2B2C): uma empresa oferece produtos ou serviços a uma empresa que seja sua cliente, a qual, por sua vez, mantém seus próprios clientes, para os quais o serviço ou produto é repassado;

- Consumidor-para-Empresa (C2B): essa categoria envolve, por um lado, indivíduos que utilizam a internet para vender produtos ou serviços a

\footnotetext{
${ }^{2}$ A World Wide Web (que em português significa, "Rede de alcance mundial"; também conhecida como Web e WWW) é um sistema de documentos hipermídia que são interligados e executados na Internet. Fonte: World Wide Web (2010)
} 
organizações e, por outro, aqueles que procuram vendedores a fim de que ofereçam lances, para obter produtos ou serviços de que necessitam.

- CE intranegócios: abrange todas as atividades internas que envolvem a troca de produtos, serviços ou informações entre diferentes unidades e indivíduos de uma organização. As atividades vão desde a venda de produtos corporativos a funcionários até o treinamento on-line ou os projetos de colaboração.

- Empresa-para-funcionário (B2E): é uma subcategoria do CE intranegócios na qual a organização oferece serviços, informações ou produtos a funcionários.

- E-government: Governo-Cidadão (G2C) e outros: Uma entidade governamental adquire produtos, serviços ou informação de empresas ou de cidadãos, ou, ainda, oferece esses bens a tais empresas e cidadãos.

Considerando o exposto, torna-se notória a quantidade de mercados disponíveis. É interessante que o empreendedor atente, também, que é plausível a atuação da organização em mais de um dos modelos de transações explicitados. Trata-se, na verdade, de uma conduta recomendável objetivando diversificar o número de mercados e/ou consumidores atendidos a fim de amenizar possíveis crises geradas por encolhimento de algum mercado.

No tocante aos benefícios para o empresário, Fagundes (2004), destaca inicialmente quatro grandes vantagens a serem observadas:

1) O tamanho da empresa é irrelevante: leva-se em consideração, tão somente, se o negócio é rápido (ou lento) e se está incluído na rede.

2) A localização física do empreendimento passa, também, a ser irrelevante já que as informações do produto/serviço são levadas diretamente ao consumidor final: o autor alega que a comodidade da proximidade geográfica entre cliente e vendedor é substituída por valores como agilidade na entrega e confiabilidade esta última traduzida em segurança no tratamento das informações dos clientes, por exemplo.

3) O feedback das promoções e estratégia de vendas é imediato: A partir do momento da publicação de um novo preço, por exemplo, já e possível monitorar as conseqüências e, caso necessário, adotar medidas de correção.

4) Horário de funcionamento: Uma loja virtual funciona no regime $24 \times 7$ (vinte quatro horas por dia, sete dias por semana) sem que haja necessidade de se pagar horas extras a funcionários. No caso de transações a nível internacional, devemos atentar que o fuso horário passa a ser irrelevante.

Assim, observa-se que a introdução do negócio no e-commerce deve levar em consideração diversos critérios. Uma pesquisa de mercado antes da escolha da modalidade de comércio eletrônico é indispensável para que haja viabilidade do empreendimento a fim de gozar das vantagens oferecidas quando da inserção neste mercado. 
Mesmo diante das vantagens expostas, existem sempre dúvidas, ou até receio por parte dos empreendedores no tangente às transações monetárias realizadas on-line, aparentemente pelo pouco conhecimento no assunto. Nestes termos, torna-se interessante uma breve imersão na matéria objetivando explicitar os meios de pagamento possíveis também como uma vantagem competitiva em relação ao comércio "tradicional".

Deitel et al (2004, p. 66) destaca as operações com cartões de crédito, o uso de moeda digital, o uso de cartões de débito e os pagamentos $\mathrm{P}_{2} \mathrm{P}^{3}$ dentre as opções viáveis. Contudo, daremos ênfase aos pagamentos com cartões de crédito, uma vez que, segundo o sítio iPAGARE ${ }^{4}$, se trata do meio mais recorrente no Brasil chegando a $80 \%$ das transações online, igualando a constatação em nível global.

Ao contrário do que pode se pensar, as transações on-line feitas com cartões de crédito possuem uma anatomia extremamente simples, podendo ser dividas em 5 etapas principais: o comprador informa os dados de seu cartão para a remessa; o comerciante envia as informações para o banco no qual mantém conta; o banco verifica as informações sobre a conta do comprador; a conclusão da verificação é passada para o comerciante; $\mathrm{O}$ pagamento só é recebido pelo comerciante depois que o produto for remetido.

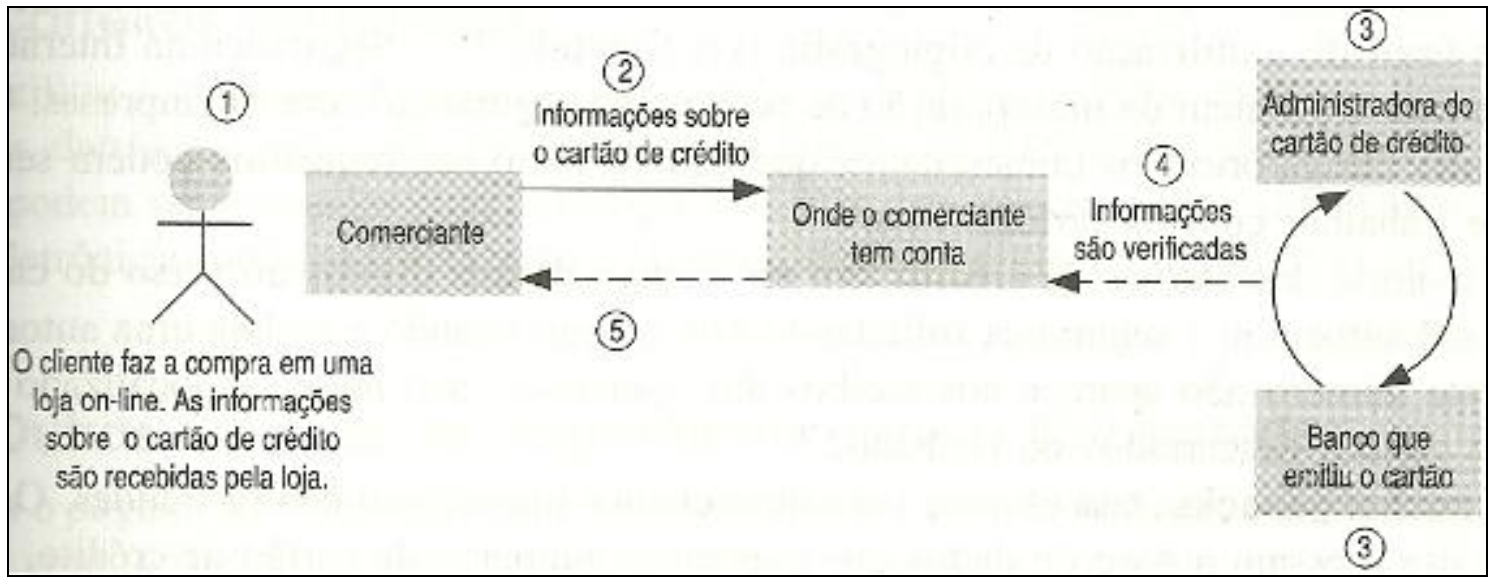

\section{Figura 1 - Etapas básicas em uma operação on-line com cartão de crédito.} Fonte: Deitel (2004, p.69)

Finalmente, propõe-se ao empreendedor a adoção do sistema de pagamentos através de cartões de crédito e/ou débito já que esses garantem segurança às duas partes e já não são considerados somente como uma opção para os clientes do comércio "tradicional" muitos os consideram necessários ou indispensáveis.

\footnotetext{
${ }^{3}$ Operações peer-to-peer (ponto a ponto) permitem transferências monetárias on-line entre consumidores. A eCash administra um serviço de pagamento que faz a transferência de dinheiro digital, via e-mail, entre duas pessoas que tenham contas em bancos habilitados pelo sistema. Fonte: Deitel et al (2004, p. 72).

${ }^{4}$ O iPAGARE é a solução de tecnologia de meios de pagamento líder em simplicidade de uso e de implantação desenvolvida pela IDEA Tecnologia. Formada por profissionais de TI capacitados para oferecer serviços de qualidade em meios de pagamento, especialmente para o setor de pequenas a médias operações de comércio eletrônico. Fonte: Institucional (2010)
} 


\section{EXPORTA FÁCIL COMO FERRAMENTA LOGÍSTICA}

Para Ballou (1993), a relevância da logística é influenciada diretamente pelos custos associados às suas atividades. Dentre os fatores de peso que causam o incremento dos custos logísticos é destacado o aumento da competição internacional.

Ora, num mercado extremamente globalizado como o atual, não fosse um obstáculo suficientemente grande para o microempresário disputar espaço contra concorrentes locais, este ainda é assombrado pelo fantasma da concorrência externa num ambiente sujeito às mais diversas flutuações causadas por inúmeras variáveis.

A idéia de se lançar no mercado internacional a fim de usufruir dos benefícios das políticas públicas no campo tributário e no acesso a recursos financeiros como linhas de crédito específicas, torna-se uma estratégia a ser considerada.

Entretanto, uma alteração no mercado (mesmo que em termos de atuação simultânea em mercados paralelos) requer maior planejamento uma vez que certamente haverão alterações no produto, na cadeia produtiva e/ou nos canais de distribuição - principalmente quando o negócio está vinculado ao comércio eletrônico.

O transporte (entrega) do produto é, sem dúvida, um dos aspectos mais relevantes a se considerar no planejamento já que “(...) é a atividade logística mais importante simplesmente porque ela absorve, em média, de um a dois terços dos custos logísticos." (BALLOU, 1993, p. 24)

No Brasil, tem-se como referência para o serviço de entrega a Empresa Brasileira de Correios e Telégrafos - ECT. Essa referência é dada pela larga acessibilidade das agências de correios no território nacional - que ultrapassam a casa das 12 mil - e pela comprovada qualidade de seus serviços.

No contexto de internacionalização, a ECT lançou, em 20 de novembro de 2000, o Exporta Fácil, instituído pela Portaria N $^{o} 710$ da Empresa Brasileira de Correios e Telégrafos ECT, numa parceria realizada junto com a Secretaria da Receita Federal - SRF, a Câmara de Comércio Exterior - CAMEX e o Banco Central do Brasil - BACEN, como integrante do Programa Brasil Empreendedor do Governo Federal.

O programa tem como público alvo empresas ou pessoas físicas que desejam exportar produtos de maneira simples, desde que as remessas não sejam superiores ao valor de US\$ $50.000,00$; os pacotes não possuam peso superior a 30kg; umas das dimensões do pacote não seja superior a $105 \mathrm{~cm}$; e a soma das dimensões do pacote não seja superior a $150 \mathrm{~cm}$.

Os trâmites burocráticos brasileiros mostram-se como um grande empecilho ao desenvolvimento. Levando isto em consideração, apresenta-se o que se considera a primeira grande vantagem competitiva desta ferramenta logística: a diminuição significativa de etapas burocráticas, já que os Correios se responsabilizam pelo despacho aduaneiro, preenchimento da nota fiscal, pela classificação do produto segundo a Nomenclatura Comum do MERCOSUL, emissão e impressão da commercial invoice ${ }^{5}$, além do acondicionamento dos produtos nas embalagens e acompanhamento da entrega.

\footnotetext{
${ }^{5}$ Fatura comercial emitida por empresas exportadoras. Fonte: Babylon (2010).
} 
Havemos de atentar, porém, que o programa supracitado conta com uma lista de proibições e restrições que deve ser sempre observada pelo exportador. Não obstante, existem, também, limitações e exigências por parte dos países importadores - o que exige planejamento e árdua pesquisa de mercado na seleção de um nicho comercial ao se utilizar esta ferramenta.

Pelo exposto, conclui-se que as vantagens oferecidas por esta ferramenta justificam o planejamento e o cuidado necessários para sua adoção, principalmente pela quantidade de atividades absorvidas pelo prestador do serviço, liberando força de trabalho que pode ser empregada em outros setores da empresa.

\section{ANÁLISE DE VIABILIDADE FINANCEIRA DA IMPLEMENTAÇÃO DAS FERRAMENTAS}

Friedman apud Freeman e Stoner (1994, p. 73) diz que "cabe à empresa usar recursos e sua energia em atividades destinadas a aumentar seus lucros, contanto que obedeçam às regras do jogo... (e) participem de uma competição aberta e livre, sem enganos e fraudes".

Assim, ainda durante os estágios de planejamento, cabe ao empreendedor medir a capacidade de seu negócio de se sustentar e gerar um retorno positivo.

No intuito de avaliar a viabilidade financeira do uso das ferramentas, fez-se uso de questionário aplicado à empresa de nome fantasia DAHAB buscando constatar quais fatores foram os maiores responsáveis por suas despesas fixas e de quais meios de pagamento advém suas receitas, ambos no mês de maio do ano corrente, para em seguida traçar comparativo com uma loja atuante no CE (comércio eletrônico).

O critério adotado para tal será a análise financeira através da definição da margem de contribuição do produto e constatação do ponto de equilíbrio do negócio, considerando seus custos fixos.

Neste sentido, cabe-nos definir os conceitos a serem usados na análise. Carlberg (2003, p. 356) alega que todas as empresas têm custos os quais estão direta ou indiretamente associados aos seus produtos ou serviços. Um dos meios mais poderosos para entender e controlar esses custos é a análise da margem de contribuição (grifo do autor). A margem de contribuição em si é calculada pela subtração dos custos fixos e variáveis requeridos para manufaturar o produto a partir da receita realizada pela venda daquele.

O mesmo autor define custos variáveis como "aqueles que mudam à medida que os níveis de produção sobem e descem". Por exemplo, o custo da matéria-prima é um custo variável, pois o aumento no número de bens fabricados gera maior demanda de matéria-prima.

Já o conceito de ponto de equilíbrio é definido da seguinte forma por Weston (2000, p. 345):

\footnotetext{
“A relação entre o volume de vendas e a lucratividade é explorada no planejamento de custo-volume-lucro ou análise do ponto de equilíbrio. A análise do ponto de equilíbrio é um método para determinar o ponto em que as vendas vão apenas cobrir os custos - isto é, o ponto em que a empresa vai equilibrar-se, servindo também para demonstrar a magnitude dos lucros ou perdas da empresa se as vendas ultrapassarem ou caírem para um nível abaixo desse ponto."
} 
A seguir, serão abordados os dados adquiridos junto a um dos sócios-proprietários da empresa. Este respondeu a questionário e foi entrevistado pelo pesquisador integrante.

\section{ANÁLISE DE DADOS - DAHAB}

A organização em questão foi qualificada da seguinte maneira: está situada à Av. João da Escossia, 1515; no Mossoró West Shopping- Mossoró/RN e inscrita no CNPJ $\mathrm{n}^{\mathrm{o}}$ 09.300.636-0001/23 sob a razão social de "SARAIVA E CASTRO LTDA". Segmentada como pequena empresa, no âmbito da tributação, é optante pelo SIMPLES. O sócioproprietário alega que escolheu o nome Dahab pelo fato de remeter à palavra ouro em árabe.

A empresa oferece bolsas, peep toes, anabelas, sandálias e rasteiras como produtos, buscando usar preços baixos como diferencial. Até a presente data, os produtos são destinados somente ao público feminino - conforme demonstrado nas figuras de 2 a 6 , respectivamente:

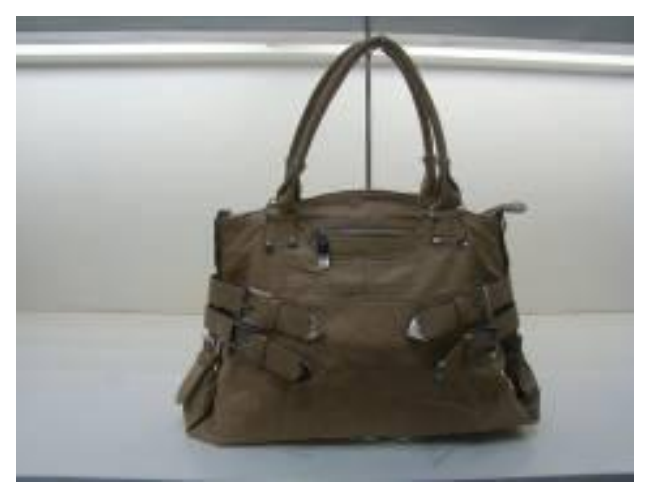

Figura 2: Exemplo de bolsa vendida na DAHAB;

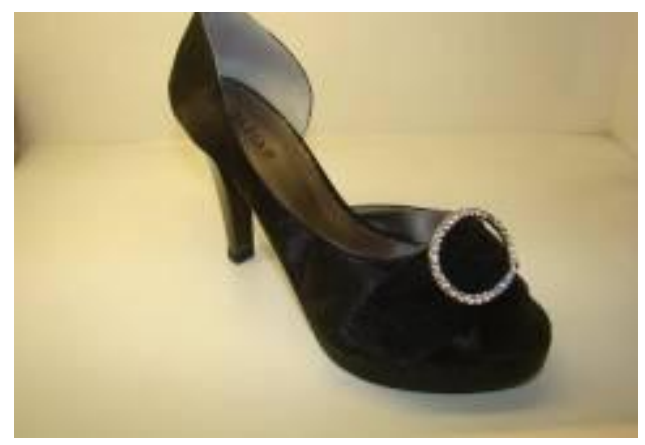

Figura 3: Exemplo de peep toe vendida na DAHAB; 


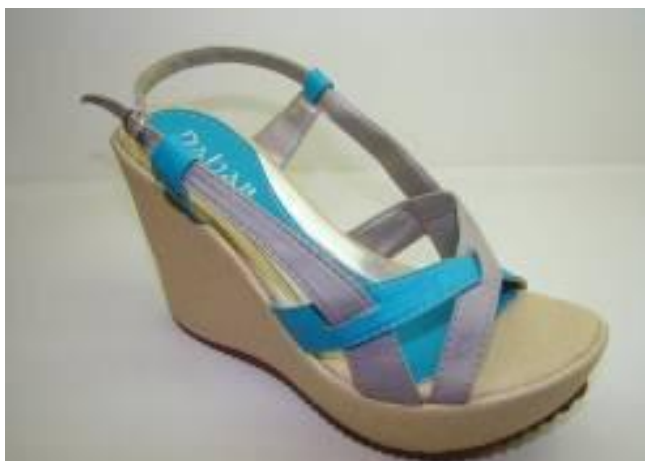

Figura 4: Exemplo de anabela vendida na DAHAB;

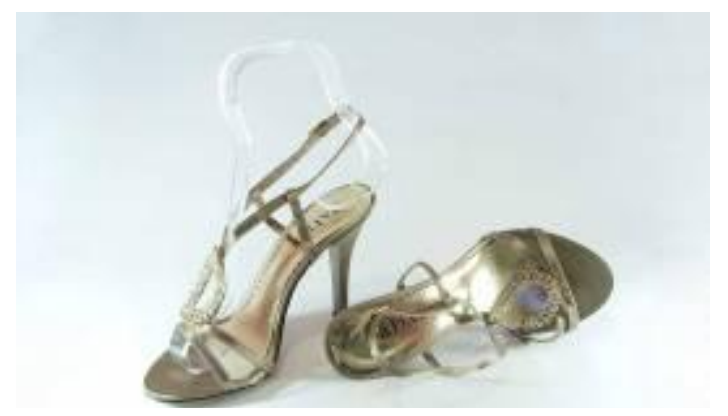

Figura 5: Exemplo de sandália vendida na DAHAB;

Fonte: www.dahab.com.br

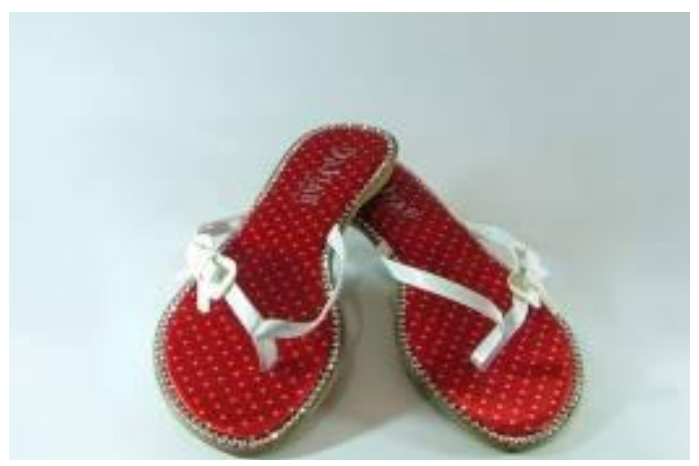

Figura 6: Exemplo de rasteira vendida na DAHAB;

A prosperidade do negócio gerou, ainda, interesse de outros investidores, o que culminou na abertura de uma nova loja através de contrato de franquia, na cidade de Fortaleza/CE, localizada à Av. Washington Soares, nº 4335, no Shopping Via Sul, $1^{\circ}$ Piso, Loja 241.

Ressalta-se que a empresa já possui sítio na web, sob o endereço http://www.dahabweb.com.br, embora não o use como loja virtual: trata-se apenas de um mostruário dos produtos oferecidos em sua loja física, divulgando, ainda, informações diversas ao usuário e potencial consumidor.

No tocante ao número de funcionários empregados na organização e suas funções, o empresário declara possuir um total de 7 funcionários por loja, sendo 4 vendedores, 1 
gerente e 2 sócios - um responsável pelo setor financeiro e outro pelo setor comercial. A hierarquia se dá conforme disposto no organograma a seguir:

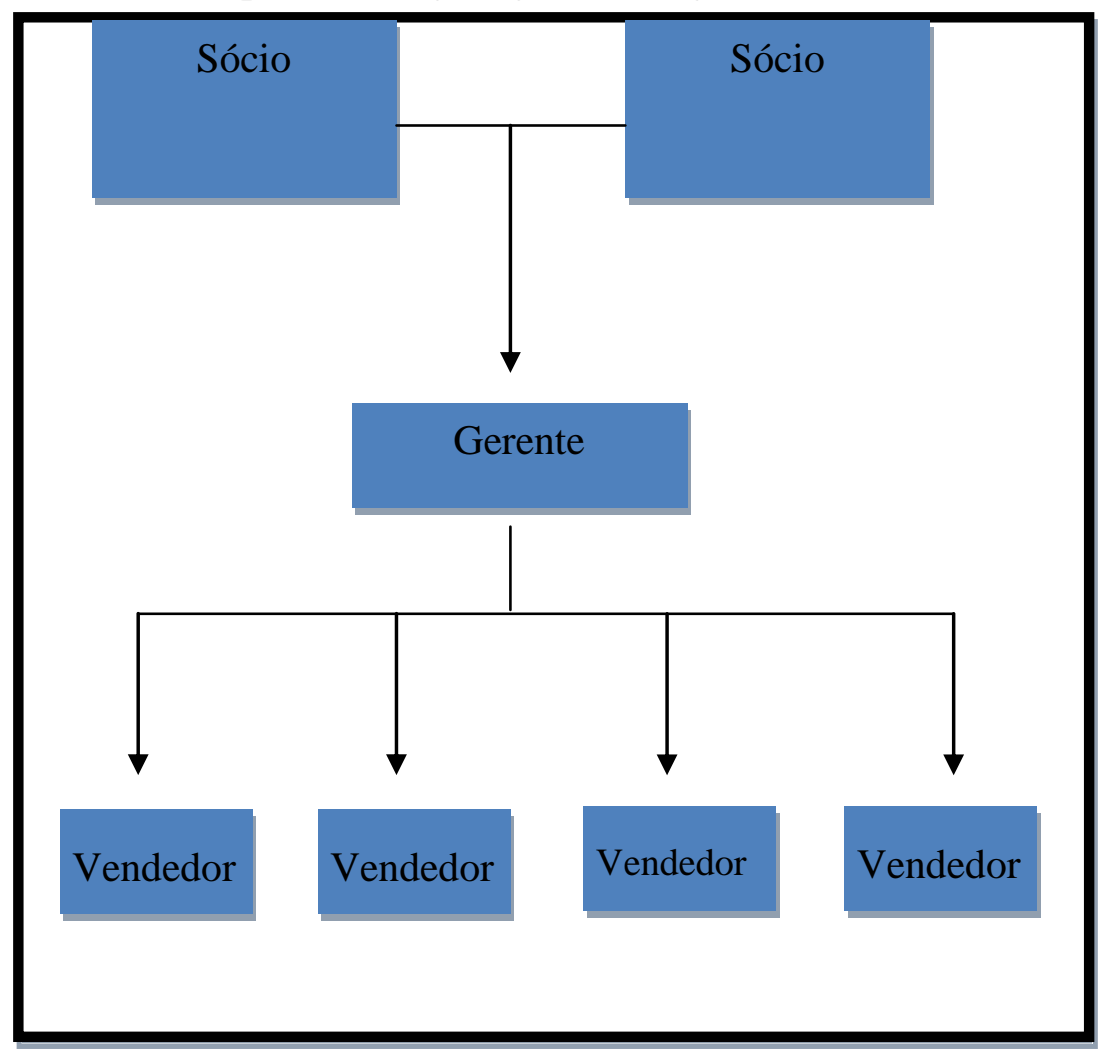

\section{Figura 7: Hierarquia dos funcionários da empresa}

\section{DAHAB;}

Embora o modelo hierárquico da loja se mostre de alguma maneira "enxuto", os custos com pessoal estão dentre os mais onerosos para a empresa, conforme demonstrado no Gráfico 1. Junto a estes, os custos com tributos, ponto, despesas operacionais e encargos financeiros diversos também figuram dentre os mais oneresos.

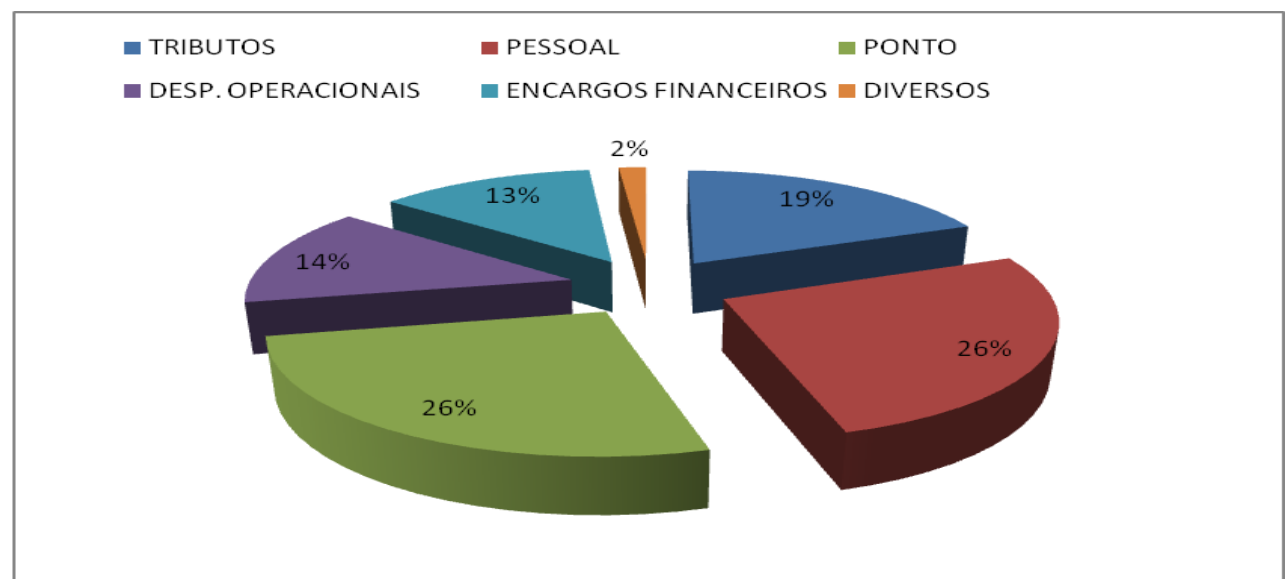

\section{Gráfico 1 - Despesas fixas da DAHAB Fonte: Elaborado pelo autor}

Contudo, as informações fornecidas são demasiadamente genéricas. Assim, tornou-se interessante o aprofundamento objetivando constatar os diversos fatores considerados na formação de cada despesa. 
Através do mesmo instrumento de pesquisa pormenorizou-se a formação de cada despesa conforme exposto a seguir:

\begin{tabular}{|c|c|}
\hline \multirow{2}{*}{ Tributos } & ICMS \\
\hline & SIMPLES \\
\hline \multirow{7}{*}{ Pessoal } & Folha de Pagamento \\
\hline & Contabilidade \\
\hline & Vales Transporte \\
\hline & FGTS \\
\hline & INSS \\
\hline & Alimentação \\
\hline & Comissão \\
\hline \multirow{5}{*}{ Ponto } & Aluguel \\
\hline & Condomínio \\
\hline & FPP \\
\hline & Energia \\
\hline & Telefone/Internet \\
\hline \multirow{6}{*}{ Despesas Operacionais } & Material de Escritório \\
\hline & Material de Limpeza \\
\hline & Serviços Terceirizados \\
\hline & Manutenção da Loja \\
\hline & Marketing \\
\hline & Sistemas \\
\hline \multirow{4}{*}{ Encargos Financeiros } & Tarifas Bancárias \\
\hline & Tarifas Cartões de Crédito \\
\hline & Tarifas Cartões de Débito \\
\hline & Pagamento de Empréstimos \\
\hline
\end{tabular}

\section{Fonte: elaborado pelo autor}

É interessante ressaltar que a soma dos custos fixos acima apresentados atinge o valor aproximado de $\mathrm{R} \$ 18.500,00$ (dezoito mil e quinhentos reais). Os custos variáveis da empresa são formados exclusivamente pelo preço de aquisição do produto junto ao fornecedor acrescido das despesas com embalagem, já que a empresa não produz os itens oferecidos ao consumidor.

A fim de facilitar o cálculo, considerou-se que a empresa ofereceu somente sandálias rasteiras aos consumidores no mês de maio de 2010. Note-se que esta é uma prática comumente adotada na bibliografia, como é possível constatar em Tracy (2004, p. 128).

Assim, seguindo com a análise dos dados, foram atribuídos pelo inquirido os seguintes valores para os custos variáveis: a) produto: $R \$ 10,00$; b) embalagem $R \$ 0,70$. O mesmo produto é oferecido ao consumidor final por $\mathrm{R} \$ 32,24$. Tais dados permitem a análise dos indicadores abordados por este estudo.

Neste caso a Margem de Contribuição unitária será calculada através da seguinte fórmula: 


\section{MARGEM DE CONTRIBUIÇÃO = VALOR DE VENDA - CUSTOS DO} PRODUTO.

Assim, temos que a margem de contribuição será de $\mathrm{R} \$ 21,54$, equivalendo, em porcentagem, a $73,01 \%$ por unidade.

Segundo Carlberg (2003, p. 360), o equilíbrio em unidades é o número de unidades, com os níveis de preço atuais para cobrir os custos fixos e variáveis sendo medido através da conforme fórmula:

\section{EQUILIBRIO EM UNIDADES = CUSTOS FIXOS TOTAIS / (PREÇO DE VENDA UNITÁRIO - CUSTOS VARIÁVEIS UNITÁRIOS)}

Assim, para atingir seu ponto de equilíbrio, a Dahab precisaria vender em torno de 859 produtos.

Cabe-nos ainda relatar o que foi possível apurar quanto aos meios de pagamento mais utilizados pelos clientes para, então, efetuarmos comparação com uma possível loja virtual.

Segundo o empresário, o rateio de vendas quanto aos meios de pagamento para o referido período se deu conforme expressado no gráfico a seguir:

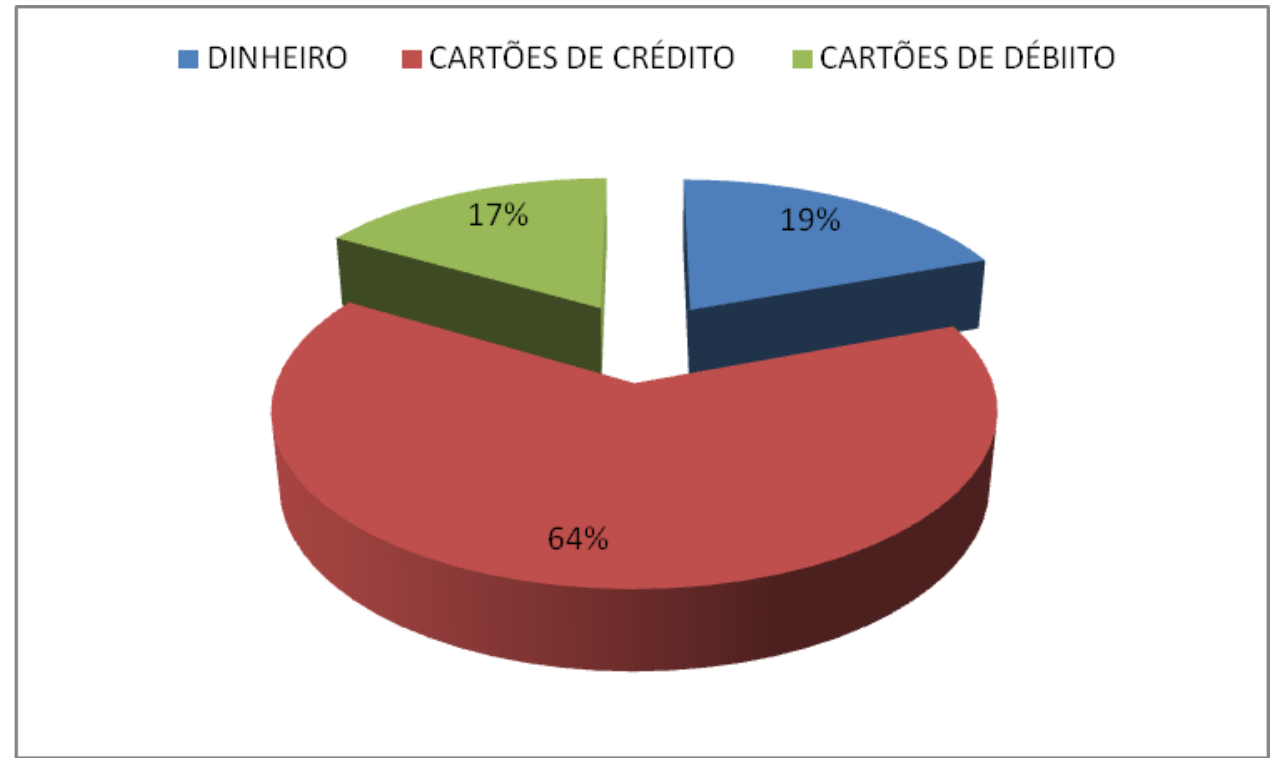

Gráfico 2 - Meios de Pagamento

Fonte: Elaborado pelo autor.

Em posse de tais dados, procederemos com comparativo em relação a uma empresa com loja virtual.

\section{COMPARATIVO: LOJA “TRADICIONAL" VERSUS LOJA VIRTUAL}

Antes de iniciar a comparação com uma possível loja virtual, cabe-nos caracterizá-la com o objetivo de medir seus custos fixos para, em seguida, analisar sua viabilidade. 
Em alternativa às lojas tradicionais da DAHAB, sugere-se a adoção de uma loja virtual hospedada no domínio já adquirido, com foco no mercado B2C - mercado este análogo ao já alvejado pela loja física: varejo para o consumidor final - com a possibilidade de aderir ao sistema just in time definido por Ballou (2004, p. 334) como:

\footnotetext{
“A programação just-in-time (JIT) é uma filosofia operacional que representa alternativa ao uso de estoques para que se possa cumprir a meta de disponibilizar os produtos certos, no lugar certo e no tempo certo".
}

Nesse caso, a ordem de compra efetuada pelo consumidor on-line, seria encaminhada diretamente ao fornecedor e a partir deste momento haveria o início do processo de fabricação do produto que, uma vez concluído, seria enviado do fornecedor diretamente para o cliente final, evitando qualquer despesa de armazenagem pela empresa ou ainda evitando gastos com o estoque.

Consideraram-se, na comparação, como custos fixos mais elevados numa empresa virtual as despesas com hospedagem e domínio, a manutenção de seu sítio na internet, gastos com segurança, banco de dados e as taxas ou tarifas de operação nas transações monetárias online. Neste sentido, no Anexo 1, há um e-mail do Gerente Comercial de empresa especializada na construção e manutenção de sites com cotação de preços para construção e manutenção do site da empresa.

Para efeito de cálculo, levando em consideração os valores demonstrados no anexo, adotou-se como custo fixo mensal o valor de $\mathrm{R} \$ 2.000,00$.

Seguindo para a determinação dos custos variáveis no mercado interno (nacional), constate-se que os valores de aquisição do produto serão exatamente os mesmo da loja física, contudo, na loja virtual serão acrescidas ao custo do produto as tarifas referentes à transação monetária on-line.

Assim, calculam-se aos seguintes valores: a) produto: $\mathrm{R} \$ 10,00$; b) embalagem $\mathrm{R} \$ 0,70$; e c) tarifas de pagamento: $\mathrm{R} \$ 0,40+6,4 \%$ do valor da venda. Contudo, há de se gerar o valor do frete, de acordo com a localização do cliente, o que incidirá de alguma maneira no valor da venda.

Para esse estudo será adotado como preço de frete para qualquer compra no mercado interno, o valor cobrado pelos correios para envio de uma encomenda Natal/RN-Porto Alegre/RS pela modalidade PAC, uma vez que se trata de um dos maiores valores de frete cobrados nessa modalidade para mercadorias saindo a partir do local referido.

A escolha do preço também é justificada por ser um valor tipicamente pessimista (é pouco provável que todas as encomendas tenham um frete tão elevado). Contudo, trata-se de forma eficaz para trazer confiabilidade à análise de viabilidade.

O valor de envio cobrado na modalidade referida entre os destinos é de $\mathrm{R} \$ 22,20$ como calculado no site dos Correios, conforme figura 8 a seguir: 


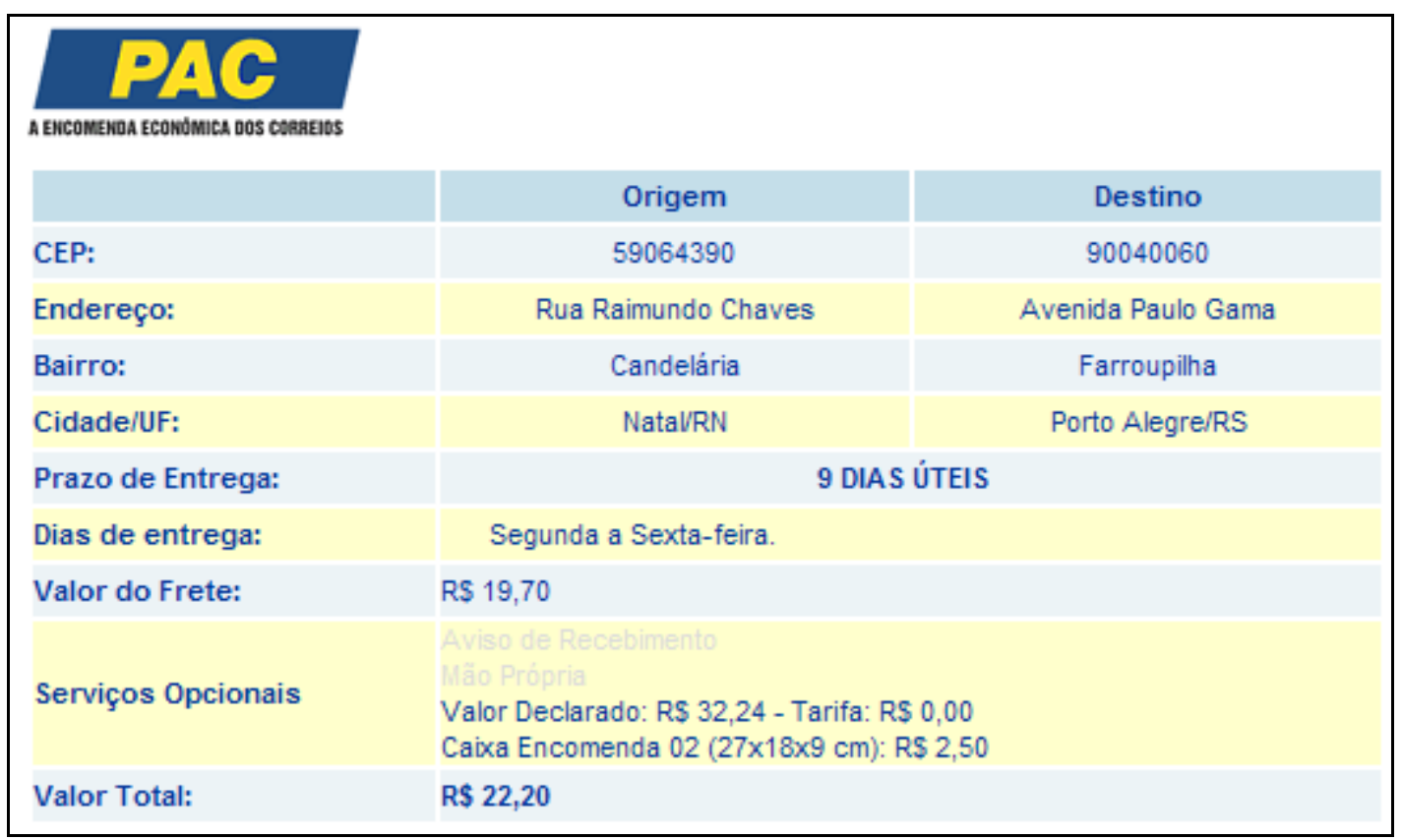

Figura 8 - Cálculo de Preço e Prazo de Entrega para Porto Alegre/RS Fonte: CORREIOS (2010)

Finalmente, de posse destes, é possível calcular a margem de contribuição e, conseqüentemente, o ponto de equilíbrio para a loja virtual.

Praticando o mesmo preço de venda da loja tradicional, a loja online teria a uma margem de contribuição de $\mathrm{R} \$ 17,92$ - corresponde a aproximadamente 56\% de uma unidade implicando em atingir o ponto de equilíbrio ao vender 112 unidades.

Nestes termos, a loja virtual mostrou-se mais viável. Contudo, a análise realizada neste estudo não leva em consideração aspectos como a vendabilidade do produto, a qual é claramente prejudicada após a adição do frete, responsável por $40 \%$ do preço final de $\mathrm{R} \$$ 54,44 .

Mesmo com o aumento de preço para o consumidor após acréscimo do valor do frete, o produto ainda é competitivo: o preço baixo adotado como estratégia pelo empresário ainda é um diferencial - seus concorrentes vendem produtos similares por valores até 3 vezes maiores como pode ser constatado em seus sítios na internet ${ }^{6}$.

Há, ainda, uma série de estratégias possíveis para contornar este ônus gerado pelo frete, dentre as quais cabe destacar a redução do preço do produto gerando necessidade de um número maior de vendas para se atingir o ponto de equilíbrio e/ou a adoção de métodos diferentes de envio.

Após averiguação das possibilidades no mercado interno, partiu-se para a análise de viabilidade no comércio exterior, levando em conta as políticas públicas disponíveis ao empresariado no intuito de gerar maior competitividade.

\footnotetext{
${ }^{6} \mathrm{Na}$ loja AREZZO, uma sandália rasteira preta, de características semelhantes, custa R $\$ 149,90$. Fonte: AREZZO (2010).
} 


\section{ADOÇÃO DO EXPORTA-FÁCIL COMO MÉTODO DE ENVIO PARA O EXTERIOR}

Para uma empresa brasileira, operar no comércio exterior significa eminentemente gozar de privilégios no âmbito tributário. Contudo, também implica em maiores custos logísticos $\mathrm{e}$, ainda, em correr maiores riscos devido à volatilidade do mercado.

Antes de efetuar as análises de margem de contribuição e ponto de equilíbrio da empresa atuando no mercado internacional, faz-se mister demonstrar algumas vantagens competitivas das quais a empresa pode usufruir ao lançar-se no comércio exterior.

\section{DRAWBACK INTEGRADO}

No âmbito dos incentivos fiscais, para a empresa em análise, sugere-se a adoção do sistema de Drawback ${ }^{7}$ Integrado. O regime especial aduaneiro foi instituído pela Portaria Conjunta $\mathrm{n}^{\circ}$ 467, de 25 de março de 2010, assinada pela Secretaria de Comércio Exterior e pela Secretaria da Receita Federal.

O Drawback Integrado suspende, por um período de um ano prorrogável por mais um ano, a incidência de tributos federais - Imposto de Importação, IPI, Contribuição para o PIS/Pasep, Cofins, Contribuição para o PIS/Pasep-Importação e Cofins-Importação - sobre aquisições no mercado interno ou externo, de forma combinada ou não, de insumos empregados ou consumidos no processo de fabricação de bens exportáveis.

O Drawback Integrado possibilita que empresas optantes pelo Sistema Integrado de Pagamento de Impostos e Contribuições das Microempresas e das Empresas de Pequeno Porte (Simples), pelo lucro presumido ou arbitrado do Imposto de Renda, sejam beneficiadas pelo sistema.

A utilização do benefício pode reduzir o preço de aquisição do produto e da embalagem em até $20 \%$, implicando na diminuição dos custos variáveis em $\mathrm{R} \$ 2,14$. Sugere-se que esta diminuição de custo seja diretamente repassada ao consumidor.

Todavia, há uma série de passos burocráticos a serem tomados antes de se solicitar os benefícios do Drawback Integrado. O pedido de acesso a este pode, inclusive, ser negado. Assim, o estudo apenas considerou a existência de tal benefício, porém, ele não será empregado na análise financeira a ser efetuada em seguida.

\section{CÁLCULO DOS CUSTOS DE ENVIO AO CONSUMIDOR INTERNACIONAL}

Tendo em vista que as configurações do produto se mantêm as mesmas tanto no mercado interno quanto no mercado internacional, serão simulados preços de frete/aquisição para dois consumidores distintos, um situado na cidade de Buenos Aires na Argentina e outro

\footnotetext{
${ }^{7}$ O regime aduaneiro especial de drawback, instituído em 1966 pelo Decreto Lei no 37, de 21/11/66, consiste na suspensão ou eliminação de tributos incidentes sobre insumos importados para utilização em produto exportado. O mecanismo funciona como um incentivo às exportações, pois reduz os custos de produção de produtos exportáveis, tornando-os mais competitivos no mercado internacional. Fonte: O regime especial de drawback (2010)
} 
residente na cidade de Washington nos Estados Unidos da America - sendo ambos calculados em ferramenta específica oferecida no próprio site dos correios.

O cálculo de frete para o consumidor argentino se dá conforme exposto a seguir na figura 9:

\begin{tabular}{|c|c|c|c|c|}
\hline \multicolumn{5}{|c|}{\begin{tabular}{|} 
Tipo de remessa: Mercadoria \\
Localidade de origem: \\
Localidade de destino: BUENOS AIRES - ARGENTINA \\
Peso real: 600 gramas
\end{tabular}} \\
\hline Modalidades & $\begin{array}{c}\text { Prazo } \\
\text { (Dias Úteis) }^{1}\end{array}$ & Preço (R\$) & $\begin{array}{c}\text { Seguro } \\
\text { Automático(R\$) } \\
\text { Apenas para objetos registrados }\end{array}$ & $\begin{array}{c}\text { Peso } \\
\text { Máximo }(\mathbf{K g})\end{array}$ \\
\hline Expresso & 4 a 6 & 77,00 & 200,00 & Peso máximo 20 \\
\hline $\begin{array}{l}\text { Leve } \\
\text { Prioritário }\end{array}$ & 4 a 7 & 37,00 & 100,00 & Peso máximo 2 \\
\hline $\begin{array}{l}\text { Leve } \\
\text { Econômico }\end{array}$ & 13 a 16 & 29,00 & 100,00 & Peso máximo 2 \\
\hline Econômico & 13 a 17 & 48,00 & 100,00 & Peso máximo 20 \\
\hline
\end{tabular}

Figura 9 - Cálculo de Preço e Prazo de Entrega para Buenos Aires / Argentina Fonte: CORREIOS (2010)

Já para o consumidor estadunidense, os valores de envio são explicitados a seguir na figura 10:

\begin{tabular}{|c|c|c|c|c|}
\hline \multicolumn{5}{|c|}{$\begin{aligned} & \text { Tipo de remessa: } \text { Mercadoria } \\
& \text { Localidade de origem: } \text { Natal - RN } \\
& \text { Localidade de destino: WASHINGTON - DC - ESTADOS UNIDOS } \\
& \text { Peso real: } 600 \text { gramas }\end{aligned}$} \\
\hline Modalidades & $\begin{array}{c}\text { Prazo } \\
\text { (Dias Úteis) }^{1}\end{array}$ & Preço (R\$) & $\begin{array}{c}\text { Seguro } \\
\text { Automático(R\$) } \\
\text { Apenas para objetos registrados }\end{array}$ & $\begin{array}{c}\text { Peso } \\
\text { Máximo (Kg) }\end{array}$ \\
\hline Expresso & 3 a 4 & 81,00 & 200,00 & Peso máximo 30 \\
\hline $\begin{array}{l}\text { Leve } \\
\text { Prioritário }\end{array}$ & 4 a 5 & 48,00 & 100,00 & Peso máximo 2 \\
\hline $\begin{array}{l}\text { Leve } \\
\text { Econômico }\end{array}$ & 13 a 18 & 41,00 & 100,00 & Peso máximo 2 \\
\hline Econômico & 13 a 19 & 50,00 & 100,00 & Peso máximo 20 \\
\hline
\end{tabular}

Figura 10 - Cálculo de Preço e Prazo de Entrega para Washington - DC / Estados Unidos

Fonte: CORREIOS (2010)

Note-se que dependendo da modalidade de envio escolhida, o valor de frete ainda se manterá muito próximo do referencial utilizado para o mercado nacional. Isto demonstra que o exporta fácil é uma ferramenta pouquíssimo dispendiosa para a empresa atuante no comércio exterior. 


\section{CÁlCULO DE MARGEM DE CONTRIBUIÇÃO E PONTO DE EQUILÍBRIO NA EMPRESA ATUANTE NO MERCADO INTERNACIONAL}

Mais uma vez, no intuito de adotar uma visão pessimista como referencial, será adotado o frete mais oneroso como padrão já que o valor deste incidirá diretamente nos custos variáveis da mercadoria.

Assim, pode-se prosseguir para as análises de margem de contribuição e ponto de equilíbrio, utilizando a mesma formulação aplicada na simulação de empresa virtual onde os custos variáveis do produto são formados por a) produto: $\mathrm{R} \$ 10,00$; b) embalagem $\mathrm{R} \$$ 0,70 ; e c) tarifas de pagamento: $\mathrm{R} \$ 0,40+6,4 \%$ do valor da venda, onde o preço de venda do produto será o mesmo do mercado interno.

Ressalta-se, que a modalide de envio adotado no cálculo foi a "Leve Econômico". Assim, chegou-se ao valor de $\mathrm{R} \$ 17,32(53,73 \%)$ para a Margem de Contribuição por unidade. Assim, o ponto de equilíbrio em unidades para a loja virtual exportando $100 \%$ de sua produção seria de atingido na $115^{\mathrm{a}}$ venda.

Contudo, a atuação exclusiva no mercado internacional não é recomendável a um empreendimento de pequeno porte devido à volatilidade da economia mundial e de seus fatores intervenientes. Assim, recomenda-se a atuação da empresa nos mercados interno e externo simultaneamente no intuito de evitar impactos gerados por mudanças bruscas em um destes.

\section{CONSIDERAÇÕES FINAIS}

A partir do estudo realizado sobre as vantagens competitivas do modelo de microempresa, adotando o e-commerce e o exporta-fácil como ferramentas de inserção no mercado externo, constatou-se que existem nichos de mercados cuja exploração é plausível tanto no mercado interno quanto no comércio internacional. Esta análise foi efetuada através de pesquisa exploratório-descritiva, apoiada na análise de dados estatísticos.

A análise das vantagens competitivas do modelo proposto apresenta, por si só, motivos suficientes para prospecção na área. Este estudo ocorreu, principalmente, através de dados bibliográficos, com os quais foi possível verificar que a análise de viabilidade financeira, feita através dos cálculos da margem de contribuição e ponto de equilíbrio, visou confirmar e ainda agregar confiabilidade ao que já havia sido constatado por outros autores.

Nesta altura, cabe acrescentar que a estratégia de uso de preço baixo adotada pelo empresário, no intuito de tornar seu produto atraente ao consumidor e competitivo diante dos concorrentes, é de notória importância, propiciando a exeqüibilidade do empreendimento já existente e ainda gerando a possibilidade de adoção do modelo em questão.

A adoção de loja virtual mostrou-se viável, principalmente pelos baixos custos fixos por ela demandados. Os próprios meios de pagamento sugeridos no modelo (cartões de crédito e débito) estão de acordo com a demanda dos clientes da empresa estudada. Contudo, o alto preço de envio da mercadoria - principalmente no mercado nacional - mostrou-se extremamente oneroso, chegando a aproximadamente $40 \%$ do valor a ser pago pelo consumidor. 
Em contrapartida, quando o produto é enviado ao exterior, embora o valor do frete ainda constitua boa parte da despesa a ser paga pelo consumidor, o montante destinado ao pagamento dos custos de envio não está muito distante dos custos constatados no mercado interno. Assim, comprova-se que o Exporta-Fácil é, de fato, uma ferramenta extremamente plausível dentro do modelo proposto.

Finalmente, o estudo mostrou-se exitoso ao constatar a viabilidade deste tipo de negócio, explicitando, também, ferramentas de uso possível por parte do empreendedor, bem como demonstrando uma série de outros segmentos que podem ser explorados nos mais diversos mercados: a loja pode vender somente em nível nacional, somente em nível internacional, ou ainda, atuar simultaneamente nos dois mercados.

\section{REFERÊNCIAS}

1. Alice Web. Disponível em: <http://aliceweb.desenvolvimento.gov.br/>. Acesso em: 22 de jun. 2010, 01:32:00.

2. AREZZO. Disponível em: <http://www.arezzo.com.br/inverno2010/\#/ptbr/colecao/colecao/rasteiras/-/32746445/cetim/preto>. Acesso em: 20 jun. 2010, 22:36:00.

3. Babylon. Disponível em: <http://www.babylon.com/definition/COMMERCIAL_INVOICE/Portuguese>. Acesso em: 20 jun. 2010, 23:07:00.

4. BATISTA, Emerson de Oliveira. Sistemas de Informação: o uso consciente da tecnologia para o gerenciamento. São Paulo: Saraiva, 2004.

5. BRASIL. Lei Complementar $n^{\mathbf{0}} \mathbf{1 2 3}$, de 14 de dezembro de 2006. Institui o estatuto da microempresa e da empresa de pequeno porte; altera dispositivos das Leis nos 8.212 e 8.213, ambas de 24 de julho de 1991, da Consolidação das Leis do Trabalho - CLT, aprovada pelo Decreto-Lei no 5.452, de 1o de maio de 1943, da Lei no 10.189, de 14 de fevereiro de 2001, da Lei Complementar no 63, de 11 de janeiro de 1990; e revoga as Leis nos 9.317, de 5 de dezembro de 1996, e 9.841, de 5 de outubro de 1999. Diário Oficial da União, Poder Executivo, Brasília, DF, 15 dez.2006. p.1. Col. 1.

6. Ministério do Desenvolvimento, Indústria e Comércio Exterior. Treinamento em Comércio Exterior. Brasília, 2006.

7. BALlOU, Ronald H. Gerenciamento da Cadeia de Suprimentos / Logística Empresarial. 5 ${ }^{\mathrm{a}}$ ed. Porto Alegre: Artmed, 2004.

8. Logística empresarial: transportes, administração de materiais e distribuição física. São Paulo: Atlas, 2008.

9. COMÉRCIO EXTERIOR > 2008 - 2007. Disponível em: $<$ http://www.desenvolvimento.gov.br/sitio/interna/interna.php?area=5\&menu=2353 $\&$ refr=608>. Acesso em: 28 de outubro de 2009, 20:45:00.

10. CORREIOS- EMPRESA BRASILEIRA DE CORREIOS E TELÉGRAFOS. Cálculo de Preço e Prazo de Entrega para Buenos Aires / Argentina. Disponível em: <http://www.correios.com.br/internacional/cfm/precos/default.cfm>. Acesso em: 20 jun. 2010, 21:25:00. 
11.

Cálculo de Preço e Prazo de Entrega para Porto Alegre/RS. Disponível

em: <http://www.correios.com.br/encomendas/prazo/default.cfm>. Acesso em: 20 jun. 2010, 20:50:00.

12.

Cálculo de Preço e Prazo de Entrega para Washington - DC / Estados

Unidos. Disponível em:

<http://www.correios.com.br/internacional/cfm/precos/default.cfm>. Acesso em: 20 jun. 2010, 21:35:00.

13. DEITEL, H. M.; DEITEL, P. J.; STEINBUHLER, K. E-business e E-commerce para administradores. São Paulo: Pearson Education do Brasil, 2004.

14. ELSENPETER, Robert C.; VELTE, Toby J. Iniciando em eBusiness. São Paulo: MAKRON Books, 2002.

15. EXPORTA FÁCIL. Disponível em: <http://www.correios.com.br/exportafacil/default.cfm>. Acesso em: 28 de outubro de 2009, 21:20:00.

16. FAGUNDES, Eduardo Mayer. Como ingressar nos negócios digitais. São Paulo: EI - Edições Inteligentes, 2004.

17. FRANCO Jr, Carlos F. E-business: tecnologia da informação e negócios na Internet. São Paulo: Atlas, 2001.

18. GIL, Antonio Carlos. Como Elaborar Projetos de Pesquisa. 4. ed. Atlas. São Paulo, 2002.

19. Institucional. Disponível em <http://ipagare.com.br/institucional>. Acesso em 22 de jun. de 2010, 01:35:00.

20. INSTITUTO BRASILEIRO DE GEOGRAFIA E ESTATÍSTICA - IBGE. Coordenação de Serviços e Comércio. As micro e pequenas empresas de comerciais e serviços no Brasil. Rio de Janeiro: IBGE. 2003.

21. LAUDON, Kenneth. C.; LAUDON, Jane P. Sistemas de Informação Gerenciais: administrando a empresa digital. São Paulo: Pearson Prentice Hall, 2004.

22. MAIA, Lerson Fernando dos Santos; OLIVEIRA, Marcus Vinicius de Faria. Trabalhos Acadêmicos: princípios, normas e técnicas. Natal: CEFET/RN, 2005.

23. MEIOS DE PAGAMENTO. Disponível em: <http://ipagare.com.br/meios-depagamento>. Acesso em 07 de junho de 2010, 21:10:00.

24. O'BRIEN, J.A. Sistemas de Informação e as decisões gerenciais na era da Internet. São Paulo: Saraiva, 2003.

25. O REGIME ESPECIAL DE DRAWBACK. Disponível em: <http://www.receita.fazenda.gov.br/aduana/Drawback/regime.htm>. Acesso em: 22 de junho de 2010, 01:29:15.

26. PORTER, M. E. Vantagem competitiva: criando e sustentando um desempenho superior. Rio de Janeiro: Campus, 1989.

27. RAMOS, Anatália Saraiva Martins; SILVA, Edwin Aldrin Januário da; ALVARENGA, Patrick Reinecke de. O papel estratégico da TI nas micro e pequenas empresas. Natal: SEBRAE/RN, 2009.

28. TRACY, John A. MBA Compacto: Finanças. Rio de Janeiro: Elsevier, 2004. 
29. TURBAN, Efraim; KING, David. Comércio eletrônico: estratégia e gestão. São Paulo: Prentice Hall, 2004.

30. TURBAN, Efraim et al. Tecnologia da informação para gestão. Tradução de Renate Schinke. 3. Ed. Porto Alegre: Bookmam, 2004.

31. VERGARA, Sylvia Constant. Projeto e Relatórios de Pesquisa em Administração. 3. Ed. São Paulo : Atlas, 2000.

32. WESTON, J. Fred; BRIGHAM, Eugene F. Fundamentos da Administração Financeira. 10. Ed. São Paulo: Pearson Makron Books, 2000.

33. World

Wide

Web.

Disponível

em:

<http://pt.wikipedia.org/wiki/World_Wide_Web>. Acesso em 22 de jun. de 2010, 01:34:00. 
APÊNDICE

QUESTIONÁRIO DE PESQUISA

INSTITUTO FEDERAL DE EDUCAÇÃO, CIÊNCIA E TECNOLOGIA DO RIO GRANDE DO NORTE

CAMPUS AVANCCADO CIDADE ALTA

CURSO DE TECNOLOGIA EM COMÉRCIO EXTERIOR

Razão Social:

IDENTIFICAÇÃO DA EMPRESA

Nome da Empresa:

Nome do Funcionário:

Cargo que ocupa na Empresa:

Endereço:

Cidade :

UF:

CEP:

Fone(s): ( )

Site:

Email:

1. Qual o porte da empresa?

\section{Caracterização da empresa}

( ) Microempresa

( ) Pequena empresa

( ) Empresa de Médio Porte

( ) Empresa de Grande Porte

2. Como se dá a hierarquia dos funcionários da empresa?

3. Quais os principais produtos ofertados pela empresa?

Análise dos Custos da Empresa 
1. Quais são os maiores custos fixos da empresa?

2. A partir de que despesas fixas são formados estes custos?

3. Qual o custo total de formação do produto e como se dá sua formação?

4. Favor enumerar custos de aquisição de um produto e seu valor final de venda. 